\title{
A STUDY ON AWARENESS OF CONSUMERS TOWARDS E-WASTE MANAGEMENT IN THE CITY OF JAIPUR
}

\author{
Dr. Ambika Bhatia \\ Associate Professor, Punjabi University Regional Centre for Information Technology and \\ Management, Mohali, Punjab (India).
}

\section{Chhavi Kiran}

Assistant Professor, Department of Commerce and Management, Sanatan Dharma College, Ambala Cantt, Haryana (India).

\section{Madhav Kapoor}

Student, Class 11th, Jayshree Periwal High School, Jaipur, Rajasthan (India).

\begin{abstract}
For any nation to grow, technology plays a crucial role. On the same route, India is witnessing growth in different spheres and one of the major growing segments of the nation is Information Technology industry. But certain hurdles are to be jumped in the journey of advancement of any nation. Growing quantity of e-waste is one of the major problems that India is dealing with now-a-days. E-waste includes all electrical and electronic components which have been discarded by the owner without the intent of reuse. An attempt has been made in this paper to study the awareness level of consumers towards health hazards caused due to e-waste, disposal practices, environmental problems resulting out of poor disposal of e-waste and awareness towards legislative policies related to e-waste management in India. Data has been gathered from 150 households of urban area of Jaipur using questionnaire. The findings indicates that with the rise in income, respondents tend to purchase more number of computers and mobile phones. Further data suggests that gender and marital status do not affect the levels of awareness amongst the respondents but education level does have an effect. It is suggested that there is need to create awareness about proper disposal of e-waste amongst people of urban areas.
\end{abstract}

Keywords : e-waste management, Information Technology industry

Cite this Article: Dr. Ambika Bhatia, Chhavi Kiran and Madhav Kapoor, a Study on Awareness of Consumers towards E-Waste Management in the City of Jaipur, Journal of Management, 6 (2), 2019, pp. 200-208.

http://www.iaeme.com/JOM/issues.asp?JType=JOM \&VType=6\&IType=2 


\section{INTRODUCTION}

Technological advancements in India are taking place at a rapid pace. In the last decade Indian Information Technology industry has witnessed fivefold growth. Reports of Ministry of Electronics and Information Technology states that more than 1000 global delivery centres were set up in about 80 countries by Indian IT-ITeS industry. This technological revolution has been very advantageous to the Indian economy but has also created the problem of e-waste. Simply stating, e-waste includes all electrical and electronic components which have been discarded by the owner without the intent of reuse. Refrigerators, air conditioners, printers, microwaves, calculators, monitors, laptops, mobile phones, hard disks, remote batteries, pen drives etc are all a part of e-waste. Globalisation has also played a key role in this. As consumers are being provided with more options of technologically advanced products at competitive prices, they are encouraged to discard old products before they complete their lifespan (Borthakur, 2012).

Table 1 Generation of E-Waste in India from 2005 to 2015

\begin{tabular}{|c|c|c|}
\hline Year & Amount & Sources \\
\hline 2005 & 0.146 million tonnes & MoEF annual report 2011-12 \\
\hline 2012 & 8 Lakh Tonnes (Predicted) & MoEF annual report 2011-12 \\
\hline 2014 & 1.41 million tonnes & STEP Global Monitor 2015 \\
\hline 2015 & 1.7 million tonnes & CPCB bulletin 2016 \\
\hline
\end{tabular}

\section{REVIEW OF LITERATURE}

Some researchers have stated that since the decision of buying and discarding electronic products is directly related to consumers, so it becomes imperative to study the attitude of such consumers (Gurauskiene, 2008). The knowledge of e-waste is marginal amongst consumers and there is a dire need to create awareness specifically in India (Kwatra et al, 2014). Willingness of consumers towards recycling e-waste is often affected by their demographic profile specially age, income level and education level whereas gender does not play a major role (Momoh and Oladebeye, 2010). The concern is that improper disposal of E-waste not also leads to various health hazards but also causes lot of environmental damage. In a study conducted in Uttar Pradesh it was revealed that majority of residents were unaware of the health problems associated with e-waste (Riti Thapar Kapoor, 2017). On the contrary, a study conducted in Botswana reveals that consumers are aware of the e-waste related risks but are illequipped with the information regarding proper methods of disposing it (Mburu \& Tuduetso, 2013). Different methods of disposing e-waste have been proposed like Recycling, Refurbishment, Inventory Management, Production-Process Modification, Volume Reduction, Landfilling, Incineration, Refinement and Regeneration (Ramachandra and Saira, 2004, Bhowmik et. al, 2014, Amankwah, 2016, Oraiopoulos et al, 2012). But out of all methods, recycling is the one which has smaller ecological footprint (Hischier, 2005). Furthermore, some researchers state that if more regulations are imposed, then it will lead to an increased recycling rate in the nation (Thi et al, 2019).

Table 2 Regulations relating to Electronic Waste in India

\begin{tabular}{|c|c|c|}
\hline Laws and Regulations & With effect from & Issuing Authority \\
\hline The Environment(Protection) Act & $23^{\text {rd }}$ May, 1986 & \multirow{3}{*}{$\begin{array}{c}\text { Ministry of } \\
\text { Environment and } \\
\text { Forests, Govt. of } \\
\text { India }\end{array}$} \\
\hline $\begin{array}{l}\text { Municipal Solid Waste (Management \& Handling) Rules } \\
1999\end{array}$ & $25^{\text {th }}$ September, 2000 & \\
\hline National Green Tribunal Act 2010 & $18^{\text {th }}$ October, 2010 & \\
\hline
\end{tabular}


A Study on Awareness of Consumers towards E-Waste Management in the City of Jaipur

\begin{tabular}{|c|c|c|}
\hline Laws and Regulations & With effect from & Issuing Authority \\
\hline E-Waste (Management \& Handling) Rules 2011 & $1^{\text {st }}$ May, 2012 & \\
\hline \multicolumn{2}{|c|}{ Source: Ministry of Environment and Forests, Govt. of India } \\
\hline
\end{tabular}

\section{OBJECTIVES}

The objective of the paper is to study the awareness level of consumers in the city of Jaipur. An attempt has been made to study the awareness towards health hazards caused due to e-waste, environmental problems resulting out of poor disposal of e-waste, disposal practices, and legislative policies on e-waste management in India.

\subsection{RATIONALE OF STUDY}

Research in the area of e-waste management is still at a nascent stage. Different aspects related to e-waste like role of informal sector in managing e-waste in developing nations, quantity of e-waste generated, importance and methods of managing e-waste and legislative aspects of ewaste management have been explored. But few surveys have been undertaken to study the awareness levels of consumers towards e-waste management in India. Numerous studies reveal that unprecedented growth of the Indian IT sector is one of the prime reasons for growing levels of e-waste. Further since Jaipur is one of the top cities which are going to be the major techno hubs of the country so consequently Jaipur has been chosen as the area of study.

\section{RESEARCH DESIGN}

The study aimed to obtain information about the awareness levels and disposal methods of ewaste as practiced by the urban population of Jaipur. A self-administered questionnaire was designed to obtain information with respect to the above-mentioned parameters. Random sampling method has been used for the purpose of gathering responses from 150 households of urban areas of Jaipur. Since empirical evidences suggest that the most used electronic items are mobiles phones and personal computers (including laptops), so these have been taken under consideration for the study. Data has been analysed using Microsoft Excel by applying different methods like averages, percentages and cross tabulations.

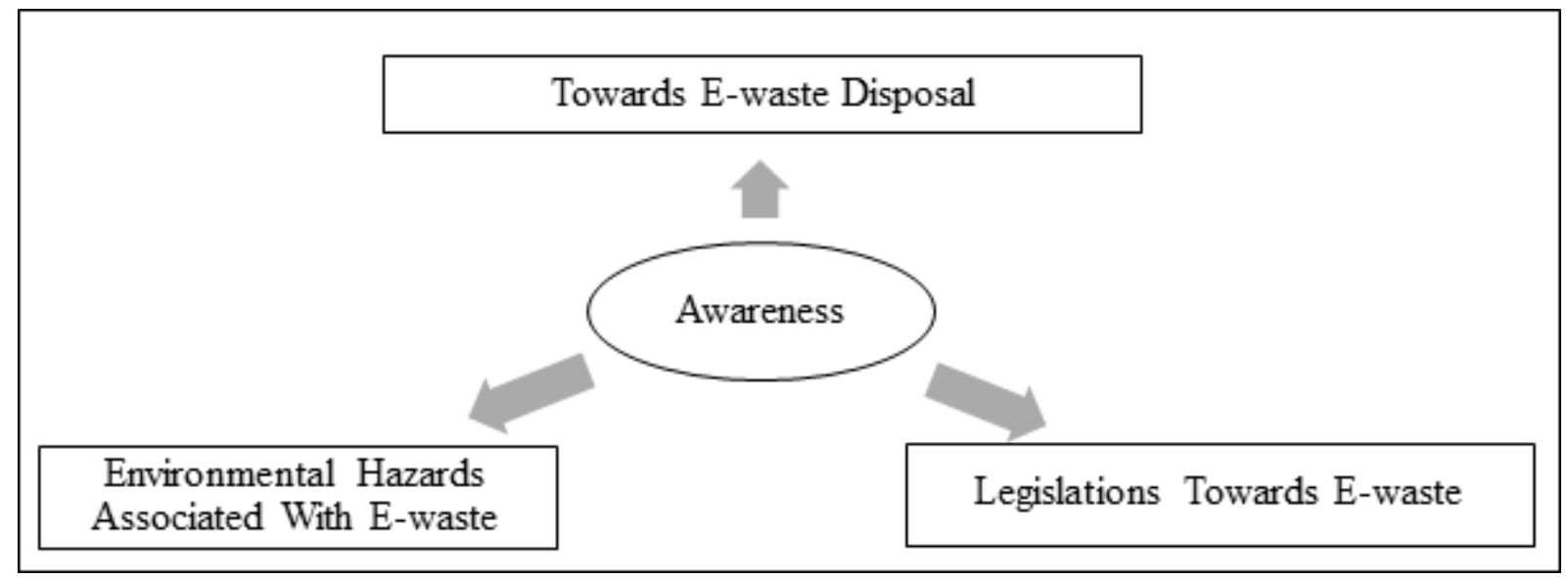

Figure 1 Awareness 


\section{DATA ANALYSIS AND FINDINGS}

\subsection{Awareness towards E-waste Disposal:}

- $78.7 \%$ of the respondents use both mobile phones and computers, $18.6 \%$ respondents use only mobile phones and $2.7 \%$ respondents do not use either mobile phones or computers. The reason for majority of respondents using both the gadgets is that both of these products are indispensable in today's time. Further the rapidly falling prices in such devices accompanied by advancements in technology gives more boost to their demand.

- $60.7 \%$ of the respondents discard household electronics after one year of use, $2.7 \%$ discard after 9 months, 6\% respondents discard after three months and 5.3\% respondents discard electronic products after fifteen days of use. This implies that respondents are not aware of the lifespan of the electronic products. Different researchers have given the description in this context. The average lifespan of computers is generally three to five years while for mobile phones it is two to three years (Vinod et al, 2011). Some studies have also revealed that over the period of time, lifespan of computers are getting narrower due to rapid advancements in technologies (Babbitt et al, 2009).

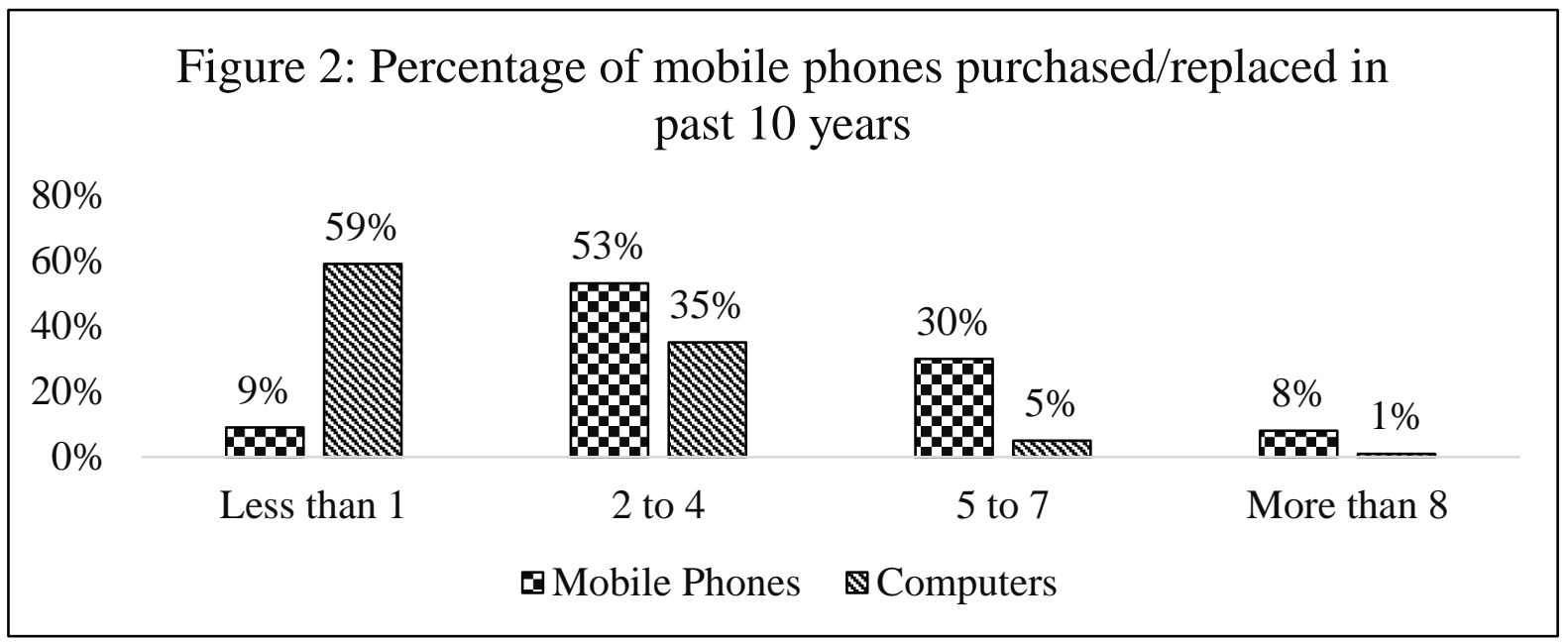

Figure 2 Percentage of mobile Phones Purchased

- Data indicates that with the rise in income, respondents tend to purchase more number of computers and mobile phones. Further data suggests gender and marital status do not affect the levels of awareness amongst the respondents. But education level has an effect as people who are either graduates or post graduates are more aware towards the disposal practices of e-waste.

- Overall $31.3 \%$ of the respondents bought new phones/computers due to physical damage of previous ones, $26.7 \%$ of respondent bought new phone or computers due to the need of greater functionality, $12 \%$ respondents bought new gadgets due to loss of function of the previous devices, and $28.7 \%$ respondents were desirous of buying newest technology available.

- Further table 3 indicates that majority of the respondents between the age group of 20 to 30 years discarded their mobile phones mainly due to desire for newest technology followed by maximum respondents from the same category who buy a new phone due to physical damage of the existing one. 
A Study on Awareness of Consumers towards E-Waste Management in the City of Jaipur

Table 3 Reasons for purchasing new mobile phones

\begin{tabular}{|c|c|c|c|c|c|c|}
\hline & $\begin{array}{c}\text { Desire for Newest } \\
\text { Technology }\end{array}$ & $\begin{array}{c}\text { Loss of } \\
\text { Function }\end{array}$ & Memes & $\begin{array}{c}\text { Need for Greater } \\
\text { Functionality }\end{array}$ & $\begin{array}{c}\text { Physical } \\
\text { Damage }\end{array}$ & Theft \\
\hline 20-30 years & $31.40 \%$ & $11.57 \%$ & $0 \%$ & $25.62 \%$ & $30.58 \%$ & $0.83 \%$ \\
\hline 31-40 years & $23.08 \%$ & $23.08 \%$ & $0 \%$ & $23.08 \%$ & $30.77 \%$ & $0 \%$ \\
\hline 41-50 years & $15.38 \%$ & $7.69 \%$ & $0 \%$ & $38.46 \%$ & $38.46 \%$ & $0 \%$ \\
\hline 51-60 years & $0 \%$ & $0 \%$ & $0 \%$ & $100.00 \%$ & $0.00 \%$ & $0 \%$ \\
\hline $\begin{array}{c}\text { Above 60 } \\
\text { years }\end{array}$ & $0 \%$ & $0 \%$ & $50.0 \%$ & $0.00 \%$ & $50.00 \%$ & $0 \%$ \\
\hline
\end{tabular}

- $49.3 \%$ respondents have kept the electronics at home that are no longer of any use, $24 \%$ either gave away or sold the unused product to a personal contact. While $20 \%$ respondents sold them to informal recyclers like scrap dealers and private collection agencies. Very few respondents gave the unused electronics to any authorized ewaste collector. This data indicates that majority of respondents are not aware of the correct methods of disposal. Some respondents are not aware that for sound disposal of e-waste it is always better to handover e-waste to an authorised recycler. But research in the area of e-waste has shown the growing involvement of informal sector (scrapdealers) in e-waste management. Convenience can be understood as a major reason for this as the scrap dealers often approach households for door to door collection of scrap items in exchange for a minimum fee.

- $50 \%$ of respondents mentioned that unused electronics can be repaired and reused, $13.3 \%$ respondents state that some components and materials of the discarded electronics can be reused, while $29.3 \%$ of the respondents state that the decision regarding discarding electronics as waste or to use them for any other purpose depends upon whether the product is functioning or not.

- $36.7 \%$ respondents know about a person who can collect unused electronics for reuse, reselling, recycling or dismantling while $34.7 \%$ respondents do not have any idea about it. Moreover $28.7 \%$ respondents are not sure about existence of people involved in such activities. This indicates that there is lack of awareness amongst the households about the presence of people or organisations who specifically deal in managing e-waste.

\subsection{Awareness regarding environmental problems resulting out of poor disposal of e- waste}

Table 4 Awareness regarding environmental problems

\begin{tabular}{|c|c|c|c|c|}
\hline SN & Statements & Yes & No & Maybe \\
\hline & & \multicolumn{3}{|c|}{ (Percentage) } \\
\hline & $\begin{array}{l}\text { Do you know that some components of electronic devices contain toxic } \\
\text { materials? }\end{array}$ & 65.3 & 16 & 18.7 \\
\hline & $\begin{array}{l}\text { If yes, then are you aware that these toxic materials need special } \\
\text { treatment for environmentally sound disposal? }\end{array}$ & 66.7 & 16 & 17.3 \\
\hline & $\begin{array}{c}\text { Does the disposal method used for e-waste have any impact on } \\
\text { environment? }\end{array}$ & 58.7 & 16 & 25.3 \\
\hline & Do you think that e-waste has an impact on environment? & 74.7 & 9.3 & 16 \\
\hline
\end{tabular}

- Majority (65.3\%) of the respondents are aware about the presence of toxic materials in e-waste. and of these respondents $66.7 \%$ are aware that the toxic materials needs to be dealt with carefully for ensuring environmental safety. Further $18.7 \%$ 
households are not sure about the toxic content contained in e-waste and $16 \%$ of respondents are not at all aware of it. Table 4 shows the percentage of responses for the questions pertaining to levels of awareness towards environmental problems amongst consumers. Responses indicate that majority of respondents are aware of the harmful effect of improper disposal of e-waste on the environment.

\subsection{Awareness towards legislative policies on e-waste management in India}

- Approximately $40 \%$ respondents think that there are any existing laws relating to ewaste management in the world and less than $50 \%$ of the respondents are aware about any legislations related to e-waste management in India. On the brighter side, majority $(73.3 \%)$ of respondents are of the opinion that there should be laws relating to e-waste in India. This result is supported by some other studies in which researchers have suggested that in order to manage e-waste successfully, there is a dire need of successful implementation of e-waste regulations in India. (Bhaskar and Turaga, 2017).

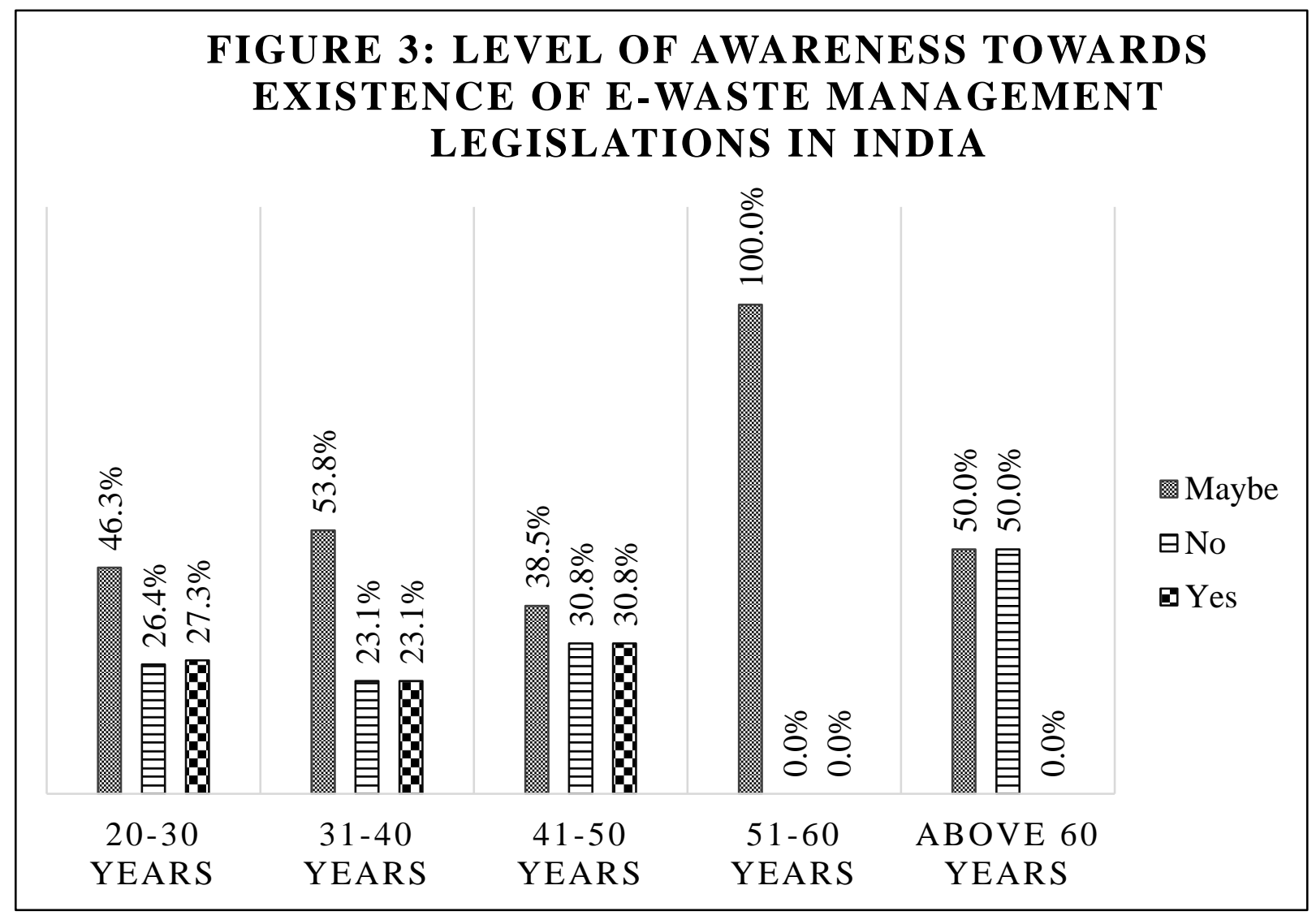

Figure 3 Level of Awareness in India 


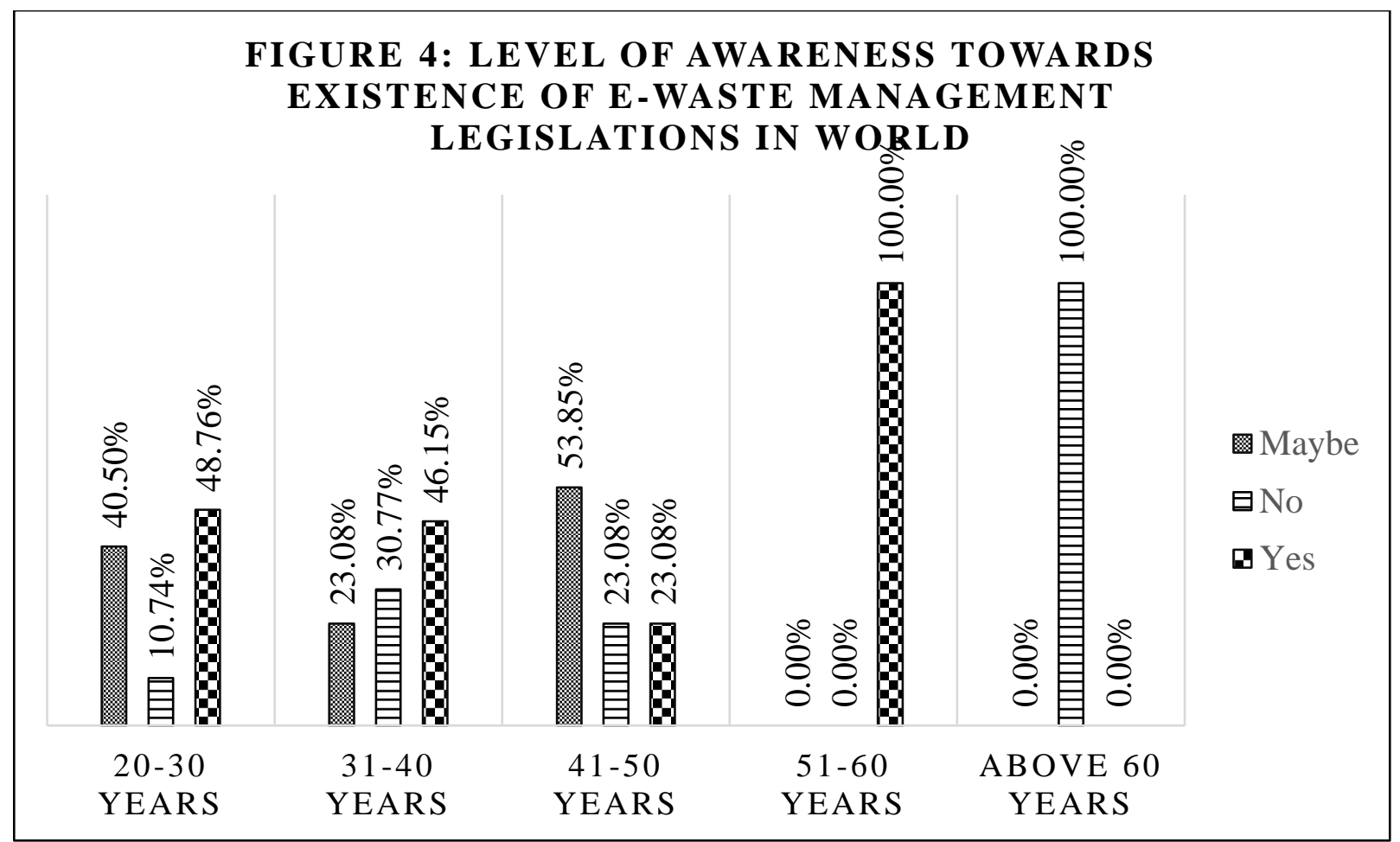

Figure 4 Level of Awareness in world

- Figure 3 shows that majority of respondents between the age group of 20 to 30 years, 31 to 40 years and 41 to 60 years are not sure about the existence of regulations related to e-waste management in India. While respondents between the age group of 31 to 40 years think that some regulations related to e-waste management exist in the world (as shown in figure 4).

\section{RECOMMENDATIONS}

On the basis of the survey conducted it is suggested that there is need to create awareness about proper disposal of e-waste amongst people of urban areas. Since education has an important role to play so, people who are either graduate or the ones possessing a higher qualification can make the citizens of their locality aware about e-waste. More awareness campaigns can be organised by individuals, Non- Government organisations and by Government organisations to equip people with the information about harmful effects of e-waste. Further one of the major concerns is that e-waste is being dealt with only informal sources like scrap dealers. Usually women and small children are engaged in e-waste recycling sites who are not aware of the ill effects of improper disposal. Consequently there is need to develop formal e-waste recycling system in the country.

E-waste can be managed using the $3 \mathrm{R}$ approach (Reduce, Reuse and Recycle). Since electronics have a longer lifespan than what is assumed by users, so citizens need to be sensitized that they should reduce the frequent replacing of electronic products. In addition to its e-waste can be re-used i.e. if the consumer is no longer willing to use the product due to requirement of new technology, then such products must be donated to a less demanding environment. This will assist in reducing the levels of e-waste in the country. Since e-waste includes some material which are valuable so it should be extracted using proper recycling methods without causing any harm to the environment. In recycling, the issue is that after extraction of useful material, either the leftovers are dumped in ground which pollutes 
groundwater or incinerated causing air pollution. Further in some cases the leftovers are discharged in rivers and small canals which causes danger to the aquatic life.

As far as the legislations are concerned, E-waste (Management) Rules were formed in 2012 and have been amended over a period of time but still there are some loopholes in its implementation which needs to be taken care of.

\section{SCOPE FOR FURTHER STUDY}

The present study has been limited to one city i.e. Jaipur as it is a growing hub of Information Technology in India. Researchers can extend the same concept for studying the behaviour of consumers towards e-waste management across different cities. Moreover for the purpose of this research, only computers and mobile phones have been studied, more products can be considered for study specifically the ones defined by Ministry of Environment and Information Technology which are included in the category of e-waste. There are numerous concerns related to management of e-waste in India and each one of those issues can be studied individually.

\section{CONCLUSION}

Electronic items have made humans dependent upon technology and rapid globalisation has provided the consumer with a wider choice to select the better technology alternatives. Due to this consumers discard an electronic device much before it completes its lifespan. The current study highlights that with the increase in purchasing power of the consumers, the tendency to replace an existing gadget is increasing. This is accompanied by lack of awareness amongst consumers towards methods of e-waste disposal. One of the problems identified is that majority of e-waste is being handled by informal sources like scrap dealers who are not aware of proper mechanism to deal with growing heaps of e-waste. Consequently such unauthorised disposal practices cause harm to the environment. Numerous issues pertain to management of e-waste and this problem needs to be addressed at war footing. But it is not possible for authorities alone to deal with it rather all citizens of the nation needs to join hands with Government for smooth and efficient management of e-waste in India.

\section{REFERENCES}

[1] Amankwah-Amoah, J, Global business and emerging economies: Towards a new perspective on the effects of e-waste. Technological Forecasting and Social Change, 105, 2016, pp 20-26.

[2] Babbitt, C. W., Kahhat, R., Williams, E., \& Babbitt, G. A., Evolution of product lifespan and implications for environmental assessment and management: a case study of personal computers in higher education. Environmental Science and Technology, 43(13), 2009, pp 5106-5112.

[3] Bhaskar, K., \& Turaga, R. M. R, India's E-Waste Rules and Their Impact on E-Waste Management Practices: A Case Study. Journal of Industrial Ecology, 22(4), 2017, pp 930942.

[4] Bhowmik, S., Agarwal, S., Nath, A., De, A, E-Waste Management is an Emerging Challenge in the Globe: A Pilot Study in Indian Scenario, International Journal of Innovative Research in Advanced Engineering, 1(4), 2014, pp 76-81.

[5] Borthakur, A., \& Singh, P, Electronic waste in India: Problems and policies. International Journal of Environmental Sciences, 3(1), 2012, pp 353-362.

[6] Gurauskiene, I, The Behaviour of Consumers as One of the Most Important Factors in Ewaste Problem. Environmental Research, Engineering and Management, 4(46), 2008, pp $56-65$ 
[7] Hischier, R., Wäger, P., \& Gauglhofer, J, Does WEEE recycling make sense from an environmental perspective?: The environmental impacts of the Swiss take-back and recycling systems for waste electrical and electronic equipment (WEEE). Environmental Impact Assessment Review, 25(5), 2005, pp 525-539.

[8] Kapoor, R. T, Assessment of Electronic Waste Management Practices utilized by Households of Govindpur Area of Allahabad District, Uttar Pradesh. International Journal Of Scientific Research, 6(1), 2017, pp 455-458.

[9] Kwatra, S., Pandey, S., \& Sharma, S, Understanding public knowledge and awareness on e-waste in an urban setting in India: a case study for Delhi. Management of Environmental Quality: An International Journal, 25(6), 2014, pp 752-765.

[10] Mburu, P. T., \& Tuduetso, T, Investigation of consumer behavior on discarding of their electrical/electronic waste: A case of Gaborone city. E3 Journal of Business Management and Economics., 4(9), 2013, pp 200-205.

[11] Momoh, J.J., Oladebeye, D.H.,Assessment of Awareness, Attitude and Willingness of people to participate in household Solid Waste Recycling Programme in Ado-Ekiti, Nigeria. Journal of Applied Sciences in Environmental Sanitation. 5(1), 2010, pp 93-105.

[12] Oomman, U. P, A Survey of Consumer Behaviour towards e-waste management in the city of Mumbai. International Journal of Research in Applied, Natural and Social Sciences, 2(8), 2014, pp 1-10.

[13] Oraiopoulos, N., Ferguson, M. E., \& Toktay, L. B, Relicensing as a secondary market strategy. Management Science, 58(5), 2012, pp 1022-1037.

[14] Ramachandra T.V and Saira V. K, Environmentally sound options for waste management, Envis Journal of Human Settlements, 2004

[15] Thi Thu Nguyen, H., Hung, R. J., Lee, C. H., \& Thi Thu Nguyen, H, Determinants of Residents' E-Waste Recycling Behavioral Intention: A Case Study from Vietnam. Sustainability, 11(1), 2019, pp 164.

[16] Vinod, K., Ruchi, G., Zillur, R. and Kazmi, A. A, Sustainability and E-waste Management Scenario in India. The First International Conference on Interdisciplinary Research and Development, 31, 2011, pp 43.1 - 43.5.

[17] https://www.businesstoday.in/current/economy-politics/bengaluru-and-hyderabad-jaipuremerges-as-india-biggest-tech-hub/story/281608.html

[18] https://tech.economictimes.indiatimes.com/news/startups/this-is-where-indias-largestsilicon-valley-is-starting-up/65529314 